\title{
AN ANALYSIS OF COSTS AWARDED BY THE ALBERTA ENERGY REGULATOR
}

\author{
SHAUN FLUKER $^{*}$ AND ERIC DALKE ${ }^{* *}$
}

\begin{abstract}
This article assesses the costs regime of the Alberta Energy Regulator (AER) (and its predecessor, the Alberta Energy Resources Conservation Board) since its inception in 1978. An analysis of the policy and legal framework governing the issuance of costs awards by the AER shows that the Board now has a wide scope of discretion in deciding whether to grant costs to a hearing participant, and the process appears less transparent than before. A statistical analysis of the AER's recent costs decisions leads to two conclusions. First, costs awards have overwhelmingly been applied to cover participants' legal fees, and second, in exercising its discretion to make cost awards, the AER seems more discriminate in its evaluation of certain types of experts.
\end{abstract}

\section{TABLE OF CONTENTS}

I. INTRODUCTION.. . . . . . . . . . . . . . . . . . . . . . . . . . . . . 805

II. StATUTORY TRIBUNALS AND COST AWARDS. . . . . . . . . . . . . . . . 808

III. THE LEGAL AND POLICY FRAMEWORK

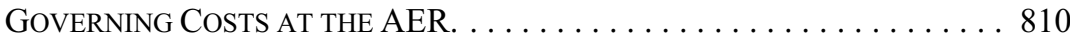

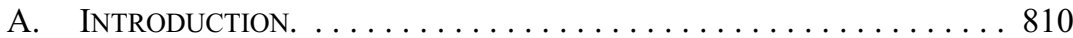

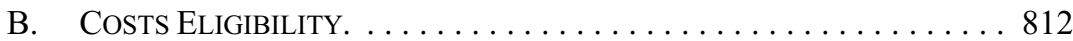

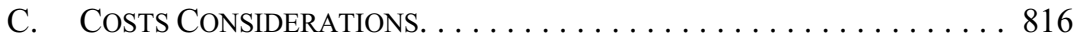

D. SumMARY On COSTS Eligibility AND CONSIDERATIONS. . . . . . . . 820

IV. QuANTITATIVE ANALYSIS OF

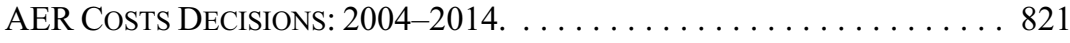

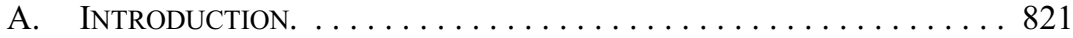

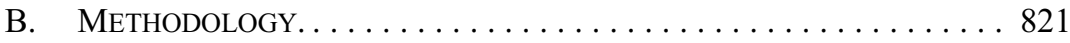

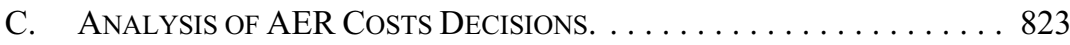

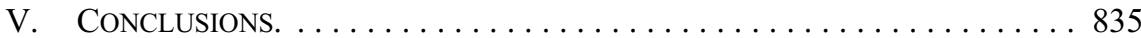

\section{INTRODUCTION}

In June 2008, Grizzly Resources Ltd. applied to the Alberta Energy Resources Conservation Board - the predecessor to the current Alberta Energy Regulator (hereinafter the Board or AER $)^{1}$ — for licences to drill two natural gas wells near Drayton Valley, Alberta. The Board granted the licences, and also denied local residents a public hearing to oppose Grizzly's application before the Board. The residents successfully took their case to the Alberta Court of Appeal and in October 2009, the Court ordered the Board to conduct the hearing, despite the fact that by this time Grizzly Resources had already drilled the wells.

Associate Professor, Faculty of Law, University of Calgary and Executive Director, Public Interest Law

JD, University of Calgary; Associate, Counsel West Law.

Over the years this agency has endured several name changes. It was the Energy Resources Conservation Board for several decades until it merged with the Alberta Public Utilities Board to form the Alberta Energy and Utilities Board in the 1990s. The Alberta Energy and Utilities Board split back into the Energy Resources Conservation Board and the Alberta Utilities Commission. In 2013, the Energy Resources Conservation Board became the Alberta Energy Regulator(AER). Accordingly, in this article we refer to this agency as either the Board or the AER. See AER, "Who We Are," online: <https://www. aer.ca/about-aer/who-we-are>. 
The Board hearing on this application was conducted in April 2010 wherein the residents expressed their health and safety concerns associated with the production of gas from these wells. After hearing and considering submissions, the Board found that existing regulatory measures were sufficient to address the residents' concerns associated with the production of hydrogen sulphide in the gas and confirmed that the issuance of well licences is in the public interest. ${ }^{2}$ At the conclusion of the hearing, the residents applied to the Board for an award of costs from Grizzly Resources to recover the approximately $\$ 30,000$ in legal fees incurred by them to participate in the April 2010 Board hearing. $^{3}$

In October 2010 the Board ruled in a 2-1 decision that the residents were not eligible for a costs award under section 28 of the Energy Resources Conservation Act. ${ }^{4}$ The dissenting member of the Board panel was of the view that the residents were entitled to some of their costs since the April 2010 hearing was conducted at the direction of the Court of Appeal. As a result, the residents would have to cover legal fees with their own funds. Not satisfied with this result, the residents returned to the Court of Appeal in January 2012 for a ruling on their eligibility for a costs award under section 28 of the Energy Resources Conservation Act. ${ }^{5}$

In Kelly v. Alberta (Energy Resources Conservation Board), ${ }^{6}$ the Court of Appeal again ruled in favour of these residents, and in doing so the Court issued the following statement on the affordability of exercising participatory rights in resource project decision-making in Alberta today:

\begin{abstract}
Granting standing and holding hearings is an important part of the process that leads to development of Alberta's resources. The openness, inclusiveness, accessibility, and effectiveness of the hearing process is an end unto itself. Realistically speaking, the cost of intervening in regulatory hearings is a strain on the resources of most ordinary Albertans, and an award of costs may well be a practical necessity if the Board is to discharge its mandate of providing a forum in which people can be heard. In other words, the Board may well be "thwarted" in discharging its mandate if the policy on costs is applied to restrictively. It is not unreasonable that the costs of intervention be borne by the resource companies who will reap the rewards of resource development. ${ }^{7}$
\end{abstract}

The Court of Appeal set aside the Board's October 2010 costs decision and directed the Board to interpret section 28 of the Energy Resources Conservation Act in a manner that broadens the eligibility for a costs award to include these residents. ${ }^{8}$ The Board subsequently reconsidered its decision and directed Grizzly Resources to pay the legal fees incurred by the residents to oppose the well licenses. ${ }^{9}$

Subsequent to this 2012 Alberta Court of Appeal decision, the regulatory framework governing the costs regime at the Board for energy project hearings changed substantively with the repeal of the Energy Resources Conservation Act and the proclamation of its

Re Grizzly Resources Ltd (26 March 2012), ECO 2012-003 at paras 1-6, online: <https://www.aer.ca/ documents/orders/cost-orders/ECO2012-003.pdf $>$ [Grizzly Resources].

Ibid at para 7.

Ibid at para 8; Energy Resources Conservation Act, RSA 2000, c E-10.

Grizzly Resources, ibid at para 9.

2012 ABCA 19, 519 AR 284 [Kelly].

Ibid at para 34.

Ibid at paras 23-27, 37.

Grizzly Resources, supra note 2. 
successor Responsible Energy Development Act ${ }^{10}$ in 2013. Prior to this, the Board's governing legislation had remained more or less the same for decades with respect to authority for the Board to award costs payable by an energy company to cover the expenses incurred by a hearing participant in the project review process.

The overall objective of this article is to disseminate our assessment of the Board's costs regime since its inception in 1978 and provide analysis of how the Board has exercised its discretion in more recent costs awards. Administrative tribunals like the Board do not have inherent jurisdiction to grant costs awards in favour of participants who appear before them. Such authority must be found in the tribunal's governing legislation. The first part of this article canvasses this area of law and highlights some key principles applicable to the matter of costs before an administrative tribunal in Canada. This provides some context for the more specific examination that follows concerning the governing legal and policy framework applicable to the Board's costs regime.

The second part of this article examines the evolution of the legal and policy framework governing the issuance of costs awards by the Board, from inception in 1978 to the current provisions under the Responsible Energy Development Act, and the Board's application of these provisions. Our examination is organized into two parts: (1) criteria governing the eligibility of a participant for a costs award; and (2) factors guiding the Board's exercise of discretion on whether to grant a costs award to an eligible participant.

The third part of this article disseminates findings from our review of all energy project costs decisions issued and published by the Board between January 2004 and December 2014. At the time of our study, these were all of the energy project costs decisions available on the AER website. ${ }^{11}$ The objective of this review was to identify trends or patterns in how the Board has exercised its discretion in making costs determinations. Each decision was coded under a standard set of content units to enable a quantitative statistical analysis, and the methodology is briefly described at the beginning of the third part.

Two primary observations arise from the statistical analysis. The first is that costs awards made by the Board have overwhelmingly been applied to cover the legal fees incurred by participants who appear before the Board in project hearings. The significance here is the extent to which legal fees have consumed Board costs awards. In the time period studied by this project, for example, the total amount of costs awarded by the Board to cover legal fees represents 65 percent of all costs awarded by the Board and in actual dollars exceeds the next highest category of expert fees by approximately $\$ 3.5$ million. When you consider that lawyers are not providing the Board with actual evidence, this finding raises questions about the purpose and conduct of Board hearings to consider energy project applications. Lawyers no doubt play an important role in the hearing process by, for example, helping to ensure that procedural fairness or natural justice is adhered to, but does that role justify consuming the

$10 \quad$ SA 2012, c R-17.3.

11 At the time of writing, the AER had issued five additional energy project costs decisions subsequent to December 2014. These five additional decisions are not incorporated into the statistical analysis in Part IV; however, reference is made to the analysis in these decisions where appropriate in Parts III and V, below. 
overwhelming majority of funds made available to landowners or groups charged with the responsibility of bringing forward evidence to contest the merits of an energy project?

The second observation from the statistical analysis is that in exercising its discretion to make costs awards, the Board seems more discriminate in its evaluation of certain types of experts - in particular, the Board seems less sensitive to the quality or relevance of the contribution made by a lawyer or an engineer versus that of another type of expert. In cases where the Board felt an ecologist or a veterinarian did not provide evidence that was relevant to the issues set for the hearing, the numbers suggest that, on average, the Board awarded a lower percentage of the claimed amount for these type of experts as compared to when the Board is critical of the hearing contribution made by a lawyer or an engineer.

In addition to these descriptive observations, we hope the following quantitative analysis provides prospective hearing participants with a better sense of what matters to the Board when it considers an application for costs and also what the average and range of costs awards has been to cover fees incurred to hire experts in a project hearing. Thus, we also provide a selection of forward-looking observations in the conclusion. This sort of information seems more pertinent than ever under the current regime because, as the analysis in this article illustrates, the Board now has a wide scope of discretion in deciding whether to grant costs to a hearing participant and the process seems less transparent than it was previously.

\section{Statutory Tribunals AND COST Awards}

It is a truism amongst scholars and practitioners in Canadian administrative law that a statutory tribunal has only those powers granted by its governing legislation. Thus, the power of a statutory tribunal to make a costs award must be set out in legislation, and many tribunals are granted this power in their enabling legislation. For example, looking only at Alberta we note that in addition to the AER, both the Alberta Utilities Commission ${ }^{12}$ and the Alberta Environmental Appeals Board ${ }^{13}$ have power to make costs awards in favour of parties who appear before them.

Canadian courts have weighed in on this question as well. The matter has been directly at issue before the Supreme Court of Canada on several occasions. In its 1986 Bell Canada v. Consumers' Association of Canada ${ }^{14}$ decision, the Supreme Court considered the power of the Canadian Radio-television and Telecommunications Commission (CRTC) to grant costs in favour of a public interest intervener. The CRTC had ordered Bell Canada to pay the legal fees incurred by the intervener to participate in a rate hearing. Bell Canada challenged the authority of the CRTC on the basis that the intervener had already received government funding and thus the CRTC costs award would amount to double recovery. Justice Le Dain, writing for a unanimous Supreme Court, held that "costs" in the context of a statutory

12 Sections 21 and 22 of the Alberta Utilities Commission Act, SA 2007, c A-37.2 provide the Commission with the power to make costs awards.

Section 96 of the Environmental Protection and Enhancement Act, RSA 2000, c E-12 provides the Board with the power to make costs awards.

[1986] 1 SCR 190. 
tribunal such as the CRTC should be understood more broadly than in its strictly litigation sense:

I would agree that the word "costs" in s. 73 must carry the same general connotation as legal costs. It cannot be construed to mean something quite different from or foreign to that general sense of the word, such as an obligation to contribute to the administrative costs of a tribunal or the grant of a subsidy to a participant in proceedings without regard to what may reasonably be considered to be the expense incurred for such participation. Thus I am of the opinion that the word "costs" must carry the general connotation of being for the purpose of indemnification or compensation. In view, however, of the nature of the proceedings before the Commission and the financial arrangements of public interest interveners, the discretion conferred on the Commission by s. 73 must, in my opinion, include the right to take a broad view of the application of the principle of indemnification or compensation. The Commission therefore should not be bound by the strict view of whether expense has been actually incurred that is applicable in the courts. It should, for example, be able to fix the expense which may be reasonably attributed to a particular participation by a public interest intervener as being deemed to have been incurred, whether or not as a result of the particular means by which the intervention has been financed there has been any actual out of pocket expense. ${ }^{15}$

As support for this ruling, Justice Le Dain referred to an earlier 1979 decision from the Alberta Court of Appeal in Green, Michaels and Associates Ltd. v. Public Utilities Board, ${ }^{16}$ where the Court similarly distinguished a costs award in an administrative context from those awarded in litigation. ${ }^{17}$

While costs awards made by statutory tribunals are thought of in the same general sense as litigation costs in terms of being compensatory, the strict rules which apply in litigation do not apply to administrative proceedings. The clearest illustration of this is perhaps the point that tribunal costs awards do not necessarily follow the event. The "winner" in an administrative proceeding is not necessarily entitled to its costs from the "loser" and, as the Alberta Court of Appeal's 2012 Kelly decision expressly states, the purpose or objective of a tribunal costs award should be as much about encouraging participation in its proceedings as it is about compensation or indemnification. ${ }^{18}$ As well, while it is often the case that a tribunal costs award results in one party before the tribunal paying funds to another party, there will be instances where the tribunal has access to public funds for making a costs award.

The 1979 Alberta Court of Appeal decision in Green and Associates is also a significant jurisprudential milestone for its endorsement of discretion in a statutory tribunal to decide on how to allocate the costs of participation in a legislated public hearing process. ${ }^{19}$ The discretionary, contextual, or fact-sensitive nature of tribunal costs determinations has evolved into the current line of authority that calls on reviewing courts to show substantial deference toward costs decisions made by statutory tribunals that have the legislative authority to make

$15 \quad$ Ibid at 207-208.

(1979), 13 AR 574 [Green and Associates].

Ibid at paras 25, 30. Green and Associates was also cited for this point in Cabre Exploration Ltd $v$. Alberta (Environmental Appeal Board), 2001 ABQB 293, 290 AR 146 at para 32; Maple Leaf Foods Inc v Winnipeg (City) Assessor, 2007 MBCA 60, 2007 MBCA 60 (CanLII) at para 12.

$18 \quad$ Kelly, supra note 6 at para 31.

Green and Associates, supra note 16 at para 25. 
such decisions. ${ }^{20}$ That being said, this judicial deference does not mean that a tribunal costs decision is completely immune from judicial review, as the 2012 Kelly judgment illustrates.

In summary, the key jurisprudential points concerning legal authority of a Canadian statutory tribunal to make costs decisions are: (1) courts will closely scrutinize whether a statutory tribunal is provided with the authority to make costs awards under its governing legislation; (2) where such authority is found, the courts give significant deference towards how the tribunal interprets the scope of its power to make cost awards; (3) the nature of statutory tribunal costs shares similarities with traditional legal costs, but is not strictly about indemnification between the parties; and (4) a tribunal costs decision made in accordance with its governing legislation and applicable policy is largely unassailable on substantive grounds.

\section{The Legal and Policy FrameWork Governing COSTS AT THE AER}

\section{A. INTRODUCTION}

This Part examines the evolution of the legal and policy framework governing the issuance of costs awards by the Board, from inception in 1978 under the now-repealed Energy Resources Conservation $A c t^{21}$ to the current provisions under the Responsible Energy Development Act. ${ }^{22}$

In order to be eligible for a costs award under the Energy Resources Conservation Act, a participant was required to show that an energy project may directly and adversely affect their interest in land. Over time, the notable issues concerning eligibility included what constitutes an interest in land and whether the adverse impact of an energy project must be to the land itself. Eligibility disputes seem to have arisen mostly in relation to cost claims made by groups or statutory entities who participated in a Board hearing but did not have a property interest impacted by the energy project in question. The need to demonstrate an interest in land was not carried forward into the current costs framework set by the Responsible Energy Development Act. Under this current framework, eligibility for costs is now wholly within the discretion of the AER and, consistent with direction from the Court of Appeal in its 2012 Kelly decision that a costs award may be necessary for a person to meaningfully exercise their hearing rights, the AER is linking eligibility for costs with the entitlement to a hearing. This change has widened the scope of costs eligibility to include persons or groups who do not have an interest in affected lands. So a person or group who is granted standing by the AER to participate in a hearing is at least eligible for a costs award under the current framework, although whether the Board actually grants costs, and in what amount, remains wholly within the discretion of the AER. at para 30; Canada (Canadian Human Rights Commission) v Canada (Attorney General), 2011 SCC 53, [2011] 3 SCR 471 at para 25. 
For hearing participants who met the eligibility test under the now-repealed Energy Resources Conservation Act, the primary criteria guiding the Board's exercise of discretion on whether to grant a costs award was always the extent to which the claimed amounts were reasonably incurred and necessarily related to hearing participation. ${ }^{23}$ However, more specific criteria have come and gone in the Board's governing legislation over time. The current list of considerations set out in the Alberta Energy Regulator Rules of Practice ${ }^{24}$ is, historically speaking, the most extensive, but the overall assessment remains whether the claim is reasonable and the expenses were necessarily incurred by a hearing participant.

The first provisions giving authority to the Board to grant costs were included in the Energy Resources Conservation Amendment Act ${ }^{25}$ in 1978. These provisions also contained rules on costs eligibility, costs considerations, an advance of costs, liability for costs, and provided the Board with the power to make regulations on costs matters. ${ }^{26}$ These statutory costs provisions remained largely unchanged until the Energy Resources Conservation Act was repealed in 2013. The intention of the Legislature in granting these new powers in 1978 was to help ensure that resource development did not result in an unjust burden being placed on local and particularly rural landowners, and thus benefits were to be limited to owners and occupants of land who may require expert as well as financial assistance to fully advance and protect their property interests. $^{27}$

Over time these statutory provisions were supplemented with subordinate legislation. The first Local Intervener's Regulation was enacted in 1978 and then amended in $1982 .{ }^{28}$ In 2001, this regulation was replaced by the Alberta Energy and Utilities Board Rules of Practice. ${ }^{29}$ The EUB Rules were replaced by the Energy Resources Conservation Board Rules of Practice in 2011. ${ }^{30}$ Each of the Local Intervener's Regulation, EUB Rules, and $E R C B$ Rules contained provisions to guide the exercise of Board discretion over costs awards as well as a number of other procedural rules relating to matters such as filing a costs claim or requesting the Board to review a costs determination. ${ }^{31}$ In addition to these rules, the Board has published directives on how it exercises its discretion to make costs awards. The current guidance is set out in Directive 031: REDA Energy Cost Claims. ${ }^{32}$ Whether these

See Energy Resources Conservation Board Rules of Practice, Alta Reg 98/2011, s 54(3)(a) [ERCB Rules]. Similar provisions were included in the costs regime of the Act and regulations over time. Alta Reg 99/2013, s 58.1 [AER Rules].

SA 1978 , c 57. This provision was initially added as section 30.1 , and upon subsequent consolidation became section 28 .

Ibid, s 30.1(10).

See Hansard discussions in relation to the enactment of the Energy Resources Conservation Amendment Act in 1978, including Alberta, Legislative Assembly, Hansard, 18th Leg, 4th Sess (17 October 1978) at 1363. The Board references these discussions more recently in Re Suncor Energy Inc (21 February 2007), ECO 2007-001 at 10-11 [Re Suncor], online: AER <https://www.aer.ca/documents/orders/ cost-orders/eco2007-001.pdf>.

Alta Reg 435/78, as amended by Alta Reg 517/82.

Alta Reg 101/2001 [EUB Rules]. Minor amendments were provided in Alta Reg 251/2001 and Alta Reg $154 / 2006$

ERCB Rules, supra note 23. The EUB Rules and the ERCB Rules were largely the same.

Section 28(4) of the Energy Resources Conservation Act provided for a local intervenor, or person who was determined by the Board to be liable to pay costs, to request a review of the costs award. Under section 60(1) the ERCB Rules, a party could request a review of a costs order within 30 days of the date of service of the order. The Responsible Energy Development Act and the AER Rules do not specifically reference the possibility of a review request by a party to a costs order, although section 42 of the Act does provide the AER with discretion to reconsider any decision it has made.

AER, "REDA Energy Cost Claims," Directive No 031 (24 February 2016), online: AER <https://www. aer.ca/documents/directives/Directive031.pdf> [Directive 031]. 
directives are binding on the Board depends on the enabling legislation and the text of the instrument itself, and in its 2012 Kelly decision the Alberta Court of Appeal ruled Directive 031 was not expressly binding such that the Board has extensive discretion to determine how it administers cost claims. ${ }^{33}$

There are currently no costs rules contained in the Responsible Energy Development Act, but the legislation provides the AER with extensive rulemaking authority governing costs. Section 61(r) allows the AER to make rules governing costs awards, advances, liability for costs, review of costs awarded, and enforcement. ${ }^{34}$ As a result, all costs rules are now found in the AER Rules. ${ }^{35}$

What follows is a more detailed look into the evolution of the legal and policy framework governing the issuance of a costs award by the Board. The examination is organized into two parts: (1) criteria governing the eligibility of a participant for a costs award; and (2) factors guiding the Board's exercise of discretion on whether to grant a costs award to an eligible participant. ${ }^{36}$ Where the Board grants a costs award to a hearing participant, the Board directs the energy company whose project is in question to pay the amount awarded.

\section{B. Costs EligibiLity}

The concept of "local intervener" was introduced as the costs eligibility test in the initial 1978 provisions added to the Energy Resources Conservation Act. This local intervener test was amended slightly in 1981, but remained largely unchanged until the repeal of the Energy Resources Conservation Act in 2013. Section 28 of the Energy Resources Conservation Act stated that persons or organizations who qualified as a local intervener could receive a costs award at the discretion of the Board. Subsections (1) and (2) of section 28 were as follows:

(1) In this section, "local intervener" means a person or a group or association of persons who, in the opinion of the Board,

(a) has an interest in, or

(b) is in actual occupation of or is entitled to occupy

land that is or may be directly and adversely affected by a decision of the Board in or as a result of a proceeding before it, but, unless otherwise authorized by the Board, does not include a person or group or association of persons whose business includes the trading in or transportation or recovery of any energy resource.

Kelly, supra note 6 at paras 15-21.

Responsible Energy Development Act, supra note 10, s 61(r).

Supra note 24.

The power to grant costs has included advance, interim, and final costs. Our analysis does not distinguish between these, and in any case the overwhelming majority of Board orders are final cost awards decided after the subject hearing has concluded. Likewise, the analysis here does not address an honorarium granted by the Board to a hearing participant. 
(2) On the claim of a local intervener or on the Board's own motion, the Board may, subject to terms and conditions it considers appropriate, make an award of costs to a local intervener. ${ }^{37}$

To establish costs eligibility under the Energy Resources Conservation Act, a participant before the Board had to demonstrate the necessary interest in land and that such interest (or in some cases the land itself) would or may be directly and adversely affected by the Board's decision on the proposed project. ${ }^{38}$

Whether a participant qualified under section 28 was central to their ability to claim costs before the Board, because there is no inherent authority for an administrative tribunal to issue costs awards and the Alberta Court of Appeal confirmed this in relation to the Board in its 2012 Kelly decision. ${ }^{39}$ Consistent with the Legislature's statements in 1978 that the purpose of the costs provisions was to assist landowners adversely affected by an energy project by funding their participation in the hearing process, ${ }^{40}$ section 28 expressly prohibited costs recovery by a person or group or association of persons whose business includes the trading in or transportation or recovery of any energy resource. Our survey of Board decisions on costs made from 2004 to 2014 suggests the notable issues concerning eligibility under the Energy Resources Conservation Act included what constitutes an interest in land and whether the adverse impact of an energy project must be to the land itself. The Board's interpretation of section 28 varied somewhat in relation to applying this test, particularly with respect to costs claims made by groups or statutory entities without a direct interest in land affect by an energy project. ${ }^{41}$

Directive 031, as it was when the Energy Resources Conservation Act was still in force, noted that statutory entities like municipalities or regional health authorities were not usually eligible for costs awards. We found costs decisions where the Board applied Directive 031 explicitly to reject a costs application by a statutory entity, but we also found decisions where the Board granted costs to a statutory entity. ${ }^{42}$

Energy Resources Conservation Act, supra note 4, ss 28(1)-(2).

Directive 031 at the time stated that the Board was to determine eligibility on a case-by-case basis and consider the nature of the proposed project, the size of the proposed project, the distance of the proposed project from the participant's land or lands, and what reasonable concerns are associated with the proposed project.

Kelly, supra note 6 at para 14.

See supra note 27.

See e.g. Re Highpine Oil \& Gas Limited (2 April 2009), ECO 2009-004, online: AER <https://www.aer. $\mathrm{ca} /$ documents/orders/cost-orders/ECO2009-004.pdf> [Highpine] (statutory body granted costs based in part on public interest); Re Compton Petroleum Corporation (20 October 2005), ECO 2005-014, online: AER < https://www.aer.ca/documents/orders/cost-orders/ECO2005-014.pdf > (statutory body not provided costs due to lack of status as local intervener); Re Suncor, supra note 27 (statutory body not provided costs due to lack of status as local intervener); Re Harvest Operations Corp (5 August 2010) ECO 2010-005, online: AER <https://www.aer.ca/documents/orders/cost-orders/ECO2010-005.pdf> (Board used discretion to issue costs related to ADR); Re Dalhousie Oil Company Limited (22 December 2010) ECO 2010-010, online: AER < https://www.aer.ca/documents/orders/cost-orders/ECO2010-010. pdf $>$ (oil and gas companies provided costs on basis of justice and fairness even though they would not qualify under section 28); Re NOVA Gas Transmission Ltd (3 July 2007), ECO 2007-005<https://www. aer.ca/documents/orders/cost-orders/ECO2007-005.pdf $>$ (oil and gas company denied costs on basis of section 28 prohibition on provision for companies who trade in, transport, or recover any energy resource).

See Re Suncor, ibid at 10-11 where the Board cited Hansard discussion on the initial 1978 provisions to support its ruling that section 28 was not intended to provide compensation to municipalities for participation in energy project hearings. However in Re Highpine, ibid at 2-4, the Board ruled it has the discretion to award costs to a statutory entity and granted a cost award to the Parkland School District. 
Likewise, we found some inconsistencies in how the Board dealt with a costs application by a public interest group. For example, in Re Total E\&P Joslyn Ltd., the Board provided local intervener status and granted a costs awards to the Oil Sands Environmental Coalition (OSEC) on the basis that a number of OSEC's members included residents living in and around the proposed projects. ${ }^{43}$ In this decision, the Board provided fairly expansive language indicating that in determining the status of an unincorporated association or coalition of hearing participants, the Board would consider the group as having the characteristics and attributes of its individual members. Yet we also found examples where the Board denied eligibility for costs under section 28 for a group because the group itself did not have a direct interest in land affected by the project. In its 2009 Re OMERS Energy Inc. decision, the Board held that the Freehold Petroleum \& Natural Gas Owners Association was ineligible for a cost award because the Association had no interest in affected land. ${ }^{44}$ The Board also confirmed its view that the right to participate in a Board hearing was a distinct determination from eligibility for costs under section 28 , because the governing provisions (right to a hearing and eligibility for costs) contained different language. ${ }^{45}$

In its October 2010 decision referenced in the introduction to this article where the Board initially denied costs eligibility to residents in Drayton Valley, the Board put the second part of the costs eligibility test directly into issue. The Board's interpretation of section 28 in that decision held that the participant must demonstrate that the energy project will or may directly affect their land:

\footnotetext{
Directive 031 is the Board's directive relating to cost claims. Directive 031 makes clear that only those persons determined to be "local interveners" by the ERCB will be eligible to recover the costs associated with participating in an ERCB proceeding. It also makes clear that there are two criteria for eligibility for local intervener funding: 1) the intervener has an interest in land or occupies or has the right to occupy land; and 2) the land in question will or may be directly and adversely affected by the Board's decision on the proposed project that is the subject of the hearing. Only if the Board determines that a party claiming costs is a local intervener does it move to consider ... the reasonableness of the costs claimed. ${ }^{46}$
}

In the Board's view, since these residents could only demonstrate a potential adverse impact to their use of land, rather than the land itself, they were not eligible for a costs award under section $28 .^{47}$ The Alberta Court of Appeal subsequently ruled in its 2012 Kelly decision that this was an unreasonable interpretation of the legislation, and that physical damage to land was not required to meet the eligibility test under section 28 . The Court ruled that eligible participants for a costs award under section 28 include those who demonstrate a potential adverse impact on their interest in land, and not just those who demonstrate adverse impact to the land itself. ${ }^{48}$ This decision also included the Court's statement, cited in the

(2 February 2012), ECO 2012-002 at paras 63-66, online: AER <https://www.aer.ca/documents/orders/ cost-orders/ECO2012-002.pdfs.

(11 August 2009), ECO 2009-008 at 6-7, online: AER <https://www.aer.ca/documents/orders/costorders/ECO2009-008.pdf>.

Ibid at 6. There are several cases where the Board makes this distinction. See e.g. Re West Energy Ltd (11 September 2012), ECO 2012-008 at para 80, online: AER <https://aer.ca/documents/orders/costorders/ECO2012-008.pdf>.

46 Re Grizzly Resources Ltd (22 October 2010), ECO 2010-007 at 5, online: AER <https://aer.ca/ documents/orders/cost-orders/ECO2010-007.pdf $>$.

Ibid.

Kelly, supra note 6 at paras 23-27. 
introduction to this article, which links funding with the right to participate in resource project decision-making. That statement bears repeating here:

Granting standing and holding hearings is an important part of the process that leads to development of Alberta's resources. The openness, inclusiveness, accessibility, and effectiveness of the hearing process is an end unto itself. Realistically speaking, the cost of intervening in regulatory hearings is a strain on the resources of most ordinary Albertans, and an award of costs may well be a practical necessity if the Board is to discharge its mandate of providing a forum in which people can be heard. In other words, the Board may well be "thwarted" in discharging its mandate if the policy on costs is applied to restrictively. It is not unreasonable that the costs of intervention be borne by the resource companies who will reap the rewards of resource development. ${ }^{49}$

The Responsible Energy Development Act did not carry forward the local intervener test for costs eligibility set out in the Energy Resources Conservation Act. Thus the test for costs eligibility seems broader now than it previously was under the old framework. In particular, the legislation no longer places an onus on the hearing participant to demonstrate a project will or may have a detriment to their interest in land in order to be eligible for a costs award. This expands the class of claimants eligible for costs to groups and other entities besides landowners and groups claiming an interest in land.

The rules on costs awards for AER hearings are now set out in Part 5 of the AER Rules. ${ }^{50}$ Section 64 of the AER Rules simply provides that the AER may award costs to a hearing participant if the AER feels it is appropriate to do so taking into account prescribed factors. A "participant" is a person who has appeared before the AER during a hearing, but excludes energy companies. The definition of "participant" is set out in section 58(1)(c) of the $A E R$ Rules as:

\begin{abstract}
A person or a group or association of persons who have been permitted to participate in a hearing for which notice of hearing is issued or any other proceeding for which the Regulator has decided to conduct binding dispute resolution, but unless otherwise authorized by the Regulator, does not include a person or group or association of persons whose business includes the trading in or transportation or recovery of any energy resource. $^{51}$
\end{abstract}

Costs eligibility under the Responsible Energy Development Act is thus now connected to the decision by the AER to conduct a hearing into the merits of an energy project, doing away with the earlier distinction made by the Board and the Energy Resources Conservation Act between hearing and costs entitlements. ${ }^{52}$ Both the decision to conduct a hearing and a

Ibid at para 34

AER Rules, supra note 24, s 58(1). Also note that Directive 031 confirms that "[o]nly those persons determined to be 'participants' by the AER will be eligible to recover the costs associated with participating in an AER proceeding" (AER, Directive 031, supra note 32 at 3 ).

AER Rules, ibid, s 58(1)(c).

The costs decisions issued by the AER under the new framework confirm that participants will be eligible for costs by virtue of being able to participate in the hearing itself. See Re Shell Canada Limited (2 May 2017), AERCO 2017-002 at 9,13, online: AER <https://www.aer.ca/documents/orders/costorders/AERCO2017-002.pdf>; Re Bonavista Energy Corporation (4 April 2017), AERCO 2017-001 at11, 13, online: AER < https://www.aer.ca/documents/orders/cost-orders/AERCO2017-001.pdf> [Re Bonavista Energy]; Re Canadian Natural Resources Ltd (15 August 2016), AERCO 2016-002 at 10,13, online: AER < https:/www.aer.ca/documents/orders/cost-orders/AERCO2016-002.pdf>; Re Pembina Pipeline Corporation (29 July 2016), AERCO 2016-001 at 9, 11, online: AER <https://www. 
determination on whether to grant costs to a hearing participant are now fully within the discretion of the AER. ${ }^{53}$ Accordingly, the current regime places more emphasis on the factors which the Board takes into account when exercising its discretion on whether to grant a costs award to a hearing participant.

\section{Costs CONSIDERATIONS}

This part looks at factors guiding the Board's exercise of discretion on whether to grant a costs award to an eligible participant. The 1978 Energy Resources Conservation Act provided the Board with discretion to award costs reasonably incurred in connection with the proceeding, and set out criteria for the Board to consider in exercising its discretion. ${ }^{54}$ These considerations were supplemented by additional criteria in the regulations. In 1981, the legislation was amended to move all criteria into the Local Intervener's Costs Regulation. ${ }^{55}$ The umbrella consideration remained whether the costs claimed were reasonable and necessarily related to the hearing, and the more specific criteria listed in section 5 of the Local Intervener's Costs Regulation were as follows:

The Board may deny a claim, in whole or in part

(a) if the Board did not hold a hearing in the proceeding,

(b) if the claim does not comply with the requirements of section 3 ,

(c) if the Board is not satisfied that the costs were reasonable and directly and necessarily related to the proceeding,

(d) the Board is not satisfied that the local intervener was in need of legal or technical assistance in the preparation and presentation of his intervention,

(e) if the Board is not satisfied that the intervention was conducted economically,

(f) if, in the opinion of the Board,

(i) the intervention and its presentation was unnecessary, irrelevant, improper, or intended to delay the proceeding before the Board, or

(ii) the claim is excessive, having regard to the nature of the proceeding and the intervention, or

(g) for any other reason the Board considers appropriate. ${ }^{56}$ them in order to be eligible for a hearing before the AER, though the Board is not obligated to conduct a hearing. For more discussion on the right to an AER hearing, see Shaun Fluker, "The Right to Public Participation in Resources and Environmental Decision-Making in Alberta”(2015) 52:3 Alta L Rev 567. 
These provisions governed cost considerations by the Board until they were replaced in 2001 with the EUB Rules enacted under the Alberta Energy and Utilities Board Act. ${ }^{57}$ These provisions later became the ERCB Rules ${ }^{58}$ and by 2011 the prescribed list of criteria had become more detailed and extensive in section 57 :

(1) The Board may award costs, in accordance with the scale of costs, to a participant if the Board is of the opinion that

(a) the costs are reasonable and directly and necessarily related to the proceeding, and

(b) the participant acted responsibly in the proceeding and contributed to a better understanding of the issues before the Board.

(2) In determining the amount of costs to be awarded to a participant, the Board may consider whether the participant did one or more of the following:

(a) asked questions on cross-examination that were unduly repetitive of questions previously asked by another participant and answered by that participant's witness;

(b) made reasonable efforts to ensure that the participant's evidence was not unduly repetitive of evidence presented by another participant;

(c) made reasonable efforts to co-operate with other participants to reduce the duplication of evidence and questions or to combine the participant's submission with that of similarly interested participants;

(d) presented in oral evidence significant new evidence that was available to the participant at the time the participant filed documentary evidence but was not filed at that time;

(e) failed to comply with a direction of the Board, including a direction on the filing of evidence;

(f) submitted evidence and argument on issues that were not relevant to the proceeding;

(g) needed legal or technical assistance to take part in the proceeding;

(h) engaged in conduct that unnecessarily lengthened the duration of the proceeding or resulted in unnecessary costs;

(i) failed to comply with this Part. ${ }^{59}$

The reference to a scale of costs in section 57(1) of the ERCB Rules is linked to Directive 031 which by this time had prescribed hourly rates for certain experts based on their experience. ${ }^{60}$ Our analysis in Part IV looks at Board costs decisions made between 2004 and

RSA 2000, c A-17.

Supra note 23.

Ibid, s 57.

The current version of Directive 031 contains the scale of costs in an appendix. See supra note 32. 
2014 and sheds some light on how the Board applied these criteria under the Energy Resources Conservation Act.

Section 64 of the AER Rules now provides the AER with power to award costs to a hearing participant if the AER feels it is appropriate to do so taking into account prescribed factors. The prescribed factors or considerations are set out in section 58.1 of the $A E R$ Rules. ${ }^{61}$ The current list is the most extensive and detailed list since the Board was first empowered to grant costs in 1978. The section reads as follows:

The Regulator shall consider one or more of the following factors when making a decision in respect of an application by a participant for an advance of funds request, an interim award of costs or a final award of costs:

(a) whether there is a compelling reason why the participant should not bear its own costs;

(b) the shared responsibility of all Alberta citizens for ensuring the protection, enhancement and wise use of the environment through individual actions;

(c) in the case of an advance of funds, whether the submission of the participant will contribute to the binding dispute resolution meeting or hearing;

(d) in the case of interim costs, whether the participant,

(i) has a clear proposal for the interim costs, and

(ii) has demonstrated a need for the interim costs;

(e) whether the participant has made an adequate attempt to use other funding sources;

(f) whether the participant has attempted to consolidate common issues or resources with other parties;

(g) in the case of final costs, whether an advance of funds or interim costs were awarded;

(h) whether the application for an advance of funds or for interim or final costs was filed with the appropriate information;

(i) whether the participant required financial resources to make an adequate submission;

(j) whether the submission of the participant made a substantial contribution to the binding resolution meeting, hearing or regulatory appeal;

(k) whether the costs were reasonable and directly and necessarily related to matters contained in the notice of hearing on an application or regulatory appeal and the preparation and presentation of the participant's submission; 
(1) whether the participant acted responsibly in the proceeding and contributed to a better understanding of the issues before the Regulator;

(m) the conduct of any participant that tended to shorten or to unnecessarily lengthen the proceeding;

(n) a participant's denial of or refusal to admit anything that should have been admitted;

(o) whether any step or stage in the proceedings was

(i) improper, vexatious or unnecessary, or

(ii) taken through negligence, mistake or excessive caution;

(p) whether the participant refused to attend a dispute resolution meeting when required by the Regulator to do so;

(q) the participant's efforts, if any, to resolve issues associated with the proceeding directly with the applicant through a dispute resolution meeting or otherwise;

(r) any other factor that the Regulator considers appropriate. ${ }^{62}$

The first thing to note with this current list is that there are a number of considerations which are new to the AER Rules. When compared with previous iterations of cost considerations, there is a significant increase in discretion for the AER on assessing whether to provide costs and the degree with which to provide them. While some considerations have appeared in previous regulations, the most recent $E R C B$ Rules did not include them. Of note, the current list restores the power for the AER to consider "any other factor" in assessing costs, which significantly increases discretion for the AER on costs matters.

There is a new emphasis in the AER Rules on whether the participant should pay costs themselves. In particular, section 58.1(a) asks whether there is a compelling reason why the participant should not bear its own costs. These provisions are bolstered by clauses (e) and (i) in section 58.1 which empower the AER to scrutinize whether the participant has made an adequate attempt to find other funding sources and to ask if they required financial support in the first place. However recent costs decisions issued by the AER suggest that, despite these new provisions in the AER Rules, the Board is not placing an emphasis on the ability of a participant to bear its own costs. Also, the AER, in accordance with the Alberta Court of Appeal's 2012 Kelly decision, is treating costs awards as a means to facilitate participation in a hearing rather than strictly as indemnification or compensation. ${ }^{63}$ Our review of AER costs decisions in Part IV, below, confirms that many of the factors set out in section 58.1 reflect prior practice by the Board in assessing costs claims.

See e.g. Re Pembina Pipeline Corporation (5 October 2016), AERCO 2016-003 at paras 12-24, online: AER < https://www.aer.ca/documents/orders/cost-orders/AERCO2016-003.pdf > [Pembina Pipeline 003]. 


\section{SUMMARY ON COSTS ELIGIBILITY AND CONSIDERATIONS}

The Board has enjoyed a significant degree of discretion in making costs determinations since it was first empowered to do so in 1978. The overarching consideration has always been whether the claimed costs are reasonable and necessarily related to the hearing in question, and up until very recently only those persons with an affected interest in land were expressly eligible for a costs award. Amendments to the legislative framework have gradually resulted in more discretion to the Board over costs matters. The applicable provisions in the Responsible Energy Development Act now simply provide the AER with rulemaking power governing costs and wide discretion to determine eligibility for costs, the factors it will consider in assessing a costs claim, and the amount of funds an eligible participant will receive to cover its hearing expenses. The onus on a participant to demonstrate an energy project may adversely impact an interest in land is no longer applicable, and thus eligibility for a costs award is potentially much broader than it used to be and is certainly not restricted to landowners.

In addition to what has already been canvassed here, the openness and transparency of the costs process has diminished with a new AER policy to limit its costs consideration to those matters in dispute between the parties:

\footnotetext{
[E]ffective immediately, the AER intends to conduct a more limited review of costs claims and will instead rely on costs submissions to identify matters arising from costs claims that require an AER decision. Specifically, the AER will review only those aspects of a costs claim that a claimant or a responder to a claim identifies in its costs submission as being in dispute. As a result, if a party responding to a costs claim does not dispute a particular amount claimed by a costs applicant, the AER will presume that part of the claim is eligible for an award in the amount sought and that the costs payee does not object to the AER awarding the amount claimed. Accordingly, going forward, only costs that a costs applicant or a responder to a costs application specifically dispute, with supporting information and reasons, will be scrutinized by the AER, and the rest of the claim may be granted without further review or intervention by the AER. ${ }^{64}$
}

According to the AER, the former line-by-line review of costs claims consumed excessive AER recourses, and thus the new process was implemented to expedite the costs process. ${ }^{65}$ Costs decisions issued in 2016 and 2017 illustrate that hearing participants and energy companies are following his new policy by coming to an agreement on costs claims outside of the AER process, which is limiting the number of claims adjudicated by the Board, but also reducing the transparency on how claims are resolved. ${ }^{66}$ Process for Reviewing Energy Costs Claims" (6 March 2014), online: AER <www.aer.ca/documents/ bulletins/AER-Bulletin-2014-07.pdf>.

$65 \quad$ Ibid.

66 See e.g., Bonavista Energy, supra note 52; Pembina Pipeline 001, supra note 52 (where the Board indicates some participants settled cost claims with the energy company). 


\section{Quantitative Analysis of \\ AER COSTS DECISIONS: 2004-2014}

\section{A. INTRODUCTION}

The previous part demonstrates that the Board's governing legal framework has set out various criteria that the Board may consider in deciding whether to make a costs award to a hearing participant. The key attribute of this legal framework is the allocation of discretionary power to the Board. In order to more fully explore this discretionary power, we conducted a content analysis of Board costs decisions in order to examine how the Board has exercised this discretion. This part disseminates the analysis. The overall objective of this study was to explore for trends or patterns in how the Board exercises its discretionary power to make costs awards.

\section{B. METHODOLOGY}

The data population for this analysis consists of 82 Board costs decisions issued from January 2004 to December 2014, all of which were downloaded from the AER website. ${ }^{67}$ This sample was chosen because this was the entire population of energy project costs decisions available on the Board's website when the study was undertaken. ${ }^{68}$ The costs decisions were coded to develop common units of analysis and entered into a Microsoft Excel spreadsheet. ${ }^{69}$ The content or coding units ultimately tracked in the study were selected by the researchers as follows: (1) case citation; (2) type of project; (3) presiding Board member; (4) type of intervener (participant) $;^{70}(5)$ lawyer on record for the intervener; (6) type of expert; (7) costs amount requested; (8) position of the energy company on the costs request; (9) costs amount awarded by the Board; and (10) reason given by the Board for the reduction.

The following picture shows how the database organizes the coded data in relation to a sample costs decision. The entire dataset contains a total of 319 rows, which means there are 319 expert cost claims covered by this study.

67 See online: AER <https://www.aer.ca/data-and-publications/orders/cost-orders>.

68 The Board changed how it processed cost applications in 2015, as noted in Part III.D, above. Accordingly, there were no costs decisions published in 2015 when the bulk of this analysis was done. Since the end of 2015, the Board has issued five energy project costs decisions which are not included in this statistical analysis.

69 In the interests of brevity for this publication, details of the methodology and the study results are largely omitted here. This information, along with the full excel worksheet, remains on file with the authors and can be provided upon request. 


\begin{tabular}{|c|c|c|c|c|c|c|c|c|c|c|c|}
\hline 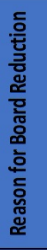 & 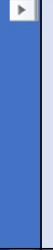 & 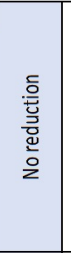 & 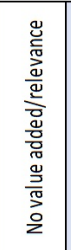 & 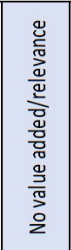 & 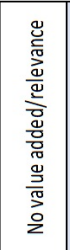 & 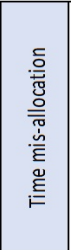 & 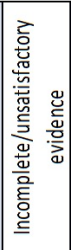 & 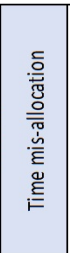 & 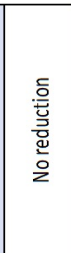 & 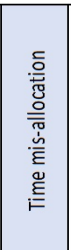 & 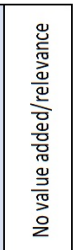 \\
\hline 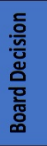 & 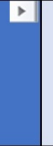 & 昜 & 岕 & 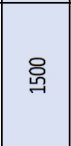 & 各 & 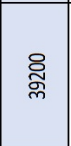 & $\begin{array}{l}\text { 总 } \\
\text { 赑 }\end{array}$ & 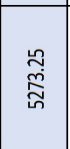 & 㶪 & $\begin{array}{l}\text { ஜु } \\
\text { o. } \\
\text { og }\end{array}$ & $\begin{array}{l}\infty \\
\stackrel{\circ}{0} \\
\stackrel{o}{\circ}\end{array}$ \\
\hline 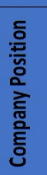 & + & 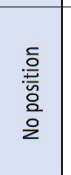 & 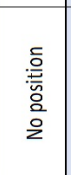 & $\begin{array}{l}\frac{\overline{0}}{\bar{y}} \\
\frac{\bar{z}}{2} \\
\frac{0}{2}\end{array}$ & 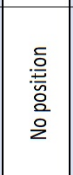 & $\begin{array}{l}\text { 흘 } \\
\frac{\overline{7}}{2} \\
\frac{0}{0} \\
\frac{0}{2}\end{array}$ & 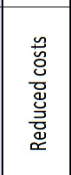 & $\begin{array}{l}\text { 흘 } \\
\frac{\bar{y}}{2} \\
\frac{0}{2} \\
\frac{a}{2}\end{array}$ & $\begin{array}{l}\text { 흠 } \\
\text { : } \\
\text { o } \\
\text { a }\end{array}$ & 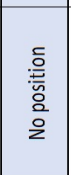 & $\begin{array}{l}\frac{}{2} \\
\frac{\bar{y}}{\circ} \\
\frac{0}{2}\end{array}$ \\
\hline 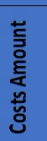 & r & 总 & 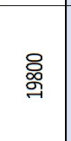 & రి & 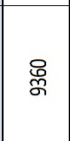 & 高 & 品 & ర్రి & 患 & 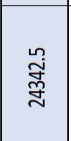 & ్ㅗㅇ \\
\hline 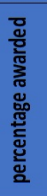 & $r$ & $\rightarrow$ & 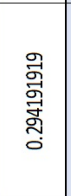 & 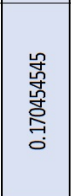 & 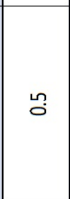 & $\stackrel{\infty}{\circ}$ & $\hat{o}$ & $\begin{array}{l}\text { 鸳 } \\
\text { 念 } \\
\text { 总 }\end{array}$ & $\rightarrow$ & 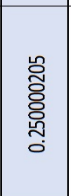 & $\stackrel{\infty}{\circ}$ \\
\hline 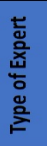 & P & 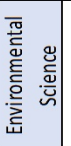 & $\begin{array}{l}\overline{\mathrm{g}} \\
\overline{\bar{z}}\end{array}$ & 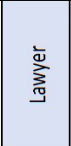 & 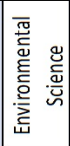 & $\sum_{\text {离 }}^{\grave{d}}$ & 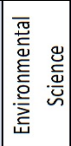 & 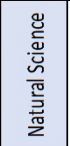 & 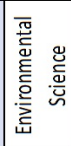 & 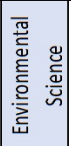 & 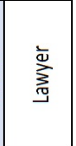 \\
\hline 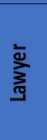 & $\Delta$ & & & 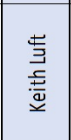 & 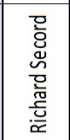 & 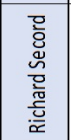 & 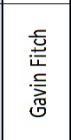 & 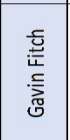 & 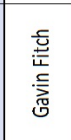 & 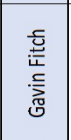 & 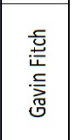 \\
\hline 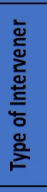 & P & 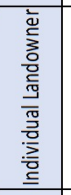 & 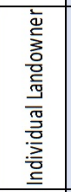 & 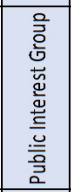 & 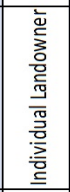 & 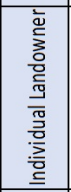 & 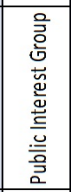 & 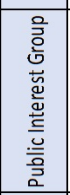 & 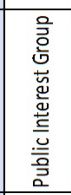 & 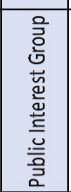 & 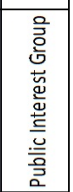 \\
\hline 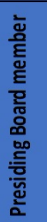 & $r$ & $\begin{array}{l}\mathbb{D} \\
\mathbb{J} \\
\Sigma\end{array}$ & $\begin{array}{l}\stackrel{\Xi}{ } \\
\stackrel{\Xi}{\Sigma} \\
\Sigma\end{array}$ & 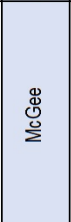 & 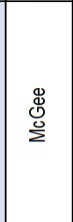 & 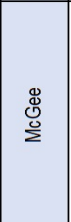 & 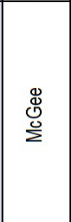 & $\begin{array}{l}\mathbb{D} \\
\stackrel{D}{\Sigma} \\
\text { L }\end{array}$ & 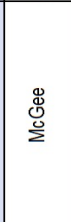 & 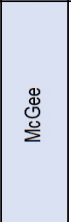 & 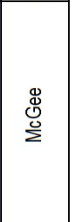 \\
\hline 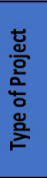 & $D$ & 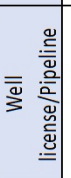 & 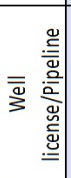 & 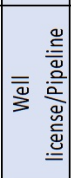 & 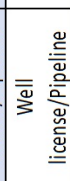 & 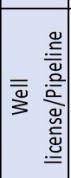 & 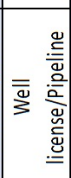 & 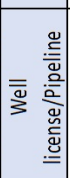 & 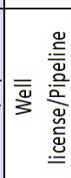 & 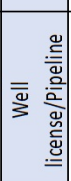 & 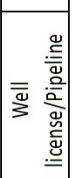 \\
\hline 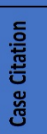 & D. & $\begin{array}{l}\text { षे } \\
\text { ठ্ं }\end{array}$ & 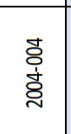 & $\begin{array}{l}\text { ㅁ } \\
\text { ठ্ं }\end{array}$ & 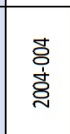 & $\begin{array}{l}\text { tे } \\
\text { ठें } \\
\text { d्र }\end{array}$ & 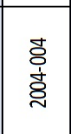 & 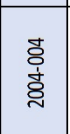 & 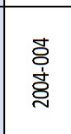 & $\begin{array}{l}\text { षे } \\
\text { ठ্ं }\end{array}$ & $\begin{array}{l}\text { రे } \\
\text { ठ্் }\end{array}$ \\
\hline
\end{tabular}




\section{ANAlysis OF AER COSTS DeCisions}

The overall objective of this study was to identify and investigate trends or patterns in how the Board exercises its discretion to make costs awards. The analysis examines the entire sample, and also looks at filtered data to specifically assess costs decisions based on independent variables such as type of expert, the Board's reasoning, or the company's position on the costs claim. Statistical observations for selected dependent variables in each dataset include calculations on the sum, the mean, the median, and the quartiles. These calculations are described in more detail below.

\section{All Costs Claim ENTRIES}

There was a total of 319 costs claim entries for the time period selected in the study (2004 to 2014). The majority of claims were submitted to cover legal fees incurred by an intervener to retain a lawyer in the project application hearing (the number of costs claims made to cover legal fees represent 40 percent of the total number of costs claims) followed by environmental scientists (representing 28 percent of all claims). Figure 1 illustrates the distribution of claims across the six categories of expert in this study:

Figure 1:

Number of Claims

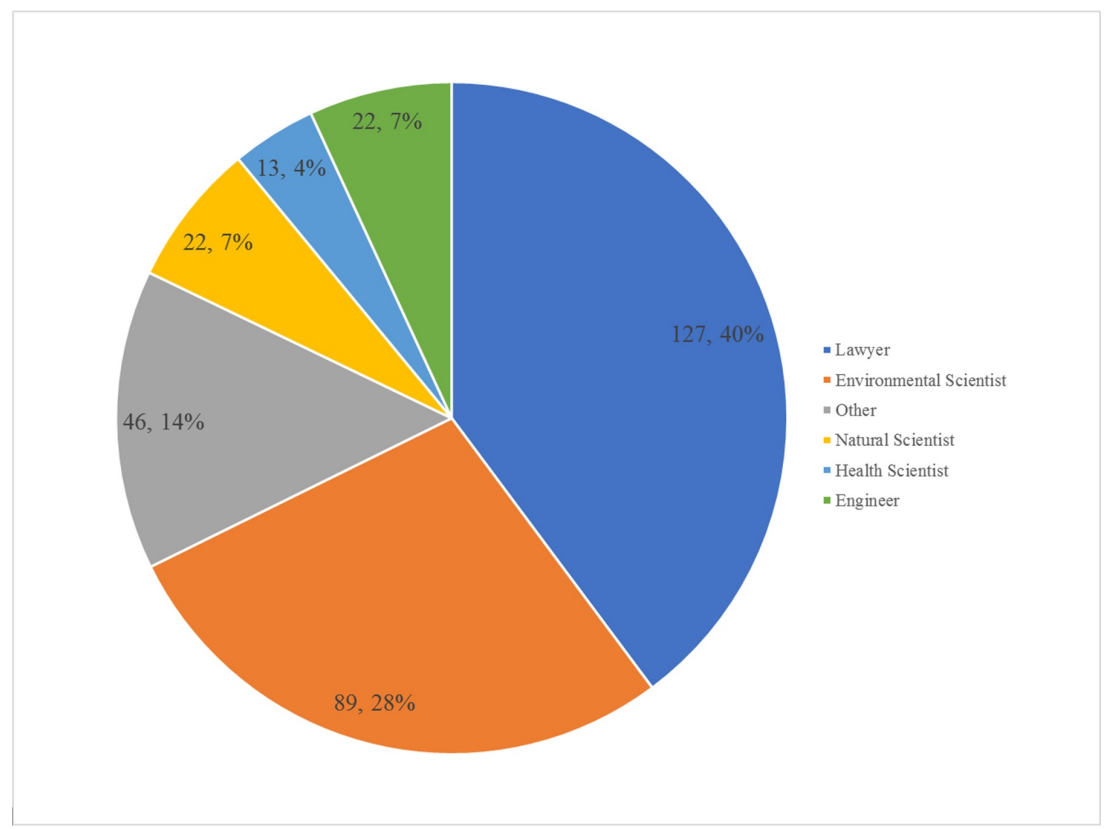

Figure 1 shows that lawyers and environmental scientists make up the majority of costs claims with a collective 216 entries representing 68 percent of all claims, and the remaining 103 entries split relatively evenly across the rest of the experts.

During the time period covered by this study, we calculated the total amount of costs claimed by interveners on behalf of their experts as $\$ 10,620,906.81$ and the total amount of 
costs awarded by the Board to cover the professional fees of experts as $\$ 7,462,708.71$. Not surprisingly, given diversity of issues raised in project hearings, there is a large range of claim amounts in the data: the minimum amount claimed for expert fees was $\$ 525$ (claimed by an individual landowner to cover the fees of an environmental scientist) and the largest amount claimed was $\$ 345,898$ (claimed by a First Nation to cover the fees of a lawyer). The largest award granted by the Board was $\$ 225,754.75$ to a First Nation to cover the fees incurred to hire a lawyer during an oil sands mine project hearing held in 2014. Table 1 sets out calculations to assess the aggregate range of costs claimed and awarded in the data:

TABLE 1:

Range of Costs Claimed and Awarded

\begin{tabular}{|l|c|c|}
\hline & Costs Claimed & Costs Awarded \\
\hline Total & $\$ 10,620,906.81$ & $\$ 7,462,708.71$ \\
\hline Minimum & $\$ 525$ & $\$ 0$ \\
\hline Maximum & $\$ 345,898$ & $\$ 225,754.75$ \\
\hline First Quartile & $\$ 6,538.50$ & $\$ 3,167.50$ \\
\hline Third Quartile & $\$ 40,605$ & $\$ 26,631.65$ \\
\hline Mean & $\$ 33,294.38$ & $\$ 23,394.07$ \\
\hline Median & $\$ 18,114$ & $\$ 10,563$ \\
\hline
\end{tabular}

The figures set out in Table 1 illustrate some important characteristics about the aggregate data in this study. The range between the first and third quartiles represents one-half of all costs claims and awards in this study. Thus we know that half of all awards made by the Board in this study are between the amounts of $\$ 3,167.50$ and $\$ 26,631.65$. The third quartile value tells us that three-quarters of all awards are equal to or less than $\$ 26,631.65$, which is significantly lower than the maximum amount awarded $(\$ 225,754.75)$. This tells us there are some large outlier awards. We might expect these larger awards to be associated with the facility or oil sands project applications which typically involve more complex hearing issues and thus consume larger amounts of expert time for hearing preparation and in front of the Board. But surprisingly perhaps, there are 14 costs awards that exceed $\$ 100,000$ and the majority of these (10 entries) relate to expert fees incurred in a hearing to consider a well licence application. Lawyer fees are the subject of 12 of these 14 relatively large awards made by the Board. These large outlier awards also skew the median values upwards, illustrated by the discrepancy between the mean (average) and median (midpoint) values in the data. The median value is resistant to outliers, and thus the median values for costs claimed $(\$ 18,114)$ and costs awarded $(\$ 10,563)$ are much lower than the mean values, and the median likely provides a more accurate figure for average amounts in the overall data for costs claimed and costs awarded. Accordingly, our analysis typically uses the median values for costs amounts as a dependent variable to describe how the Board exercised its discretion in relation to the different types of experts.

The significant difference between the median costs claimed $(\$ 18,114)$ and the median costs awarded $(\$ 10,563)$ indicates the Board generally reduces claims significantly in making awards. In fact, the mean percentage of costs claims awarded by the Board in the data is 69 percent. In other words, on average the Board awarded 69 percent of a claimed amount in the decisions analyzed here. The median percentage of costs claims awarded for all 319 entries in the data is higher at 80 percent, and this is likely because the median is skewed by 
the relatively large number of claims (127 in total) where the Board awarded the full amount claimed by an expert. Accordingly, our analysis typically uses the mean percentage awarded as a dependent variable to describe how the Board exercised its discretion in relation to the different types of experts.

This study covers 11 calendar years of data (2004 to 2014). The number of claims and total value of costs awarded varies significantly from year to year, and these figures would be dependent on the number of project hearings conducted by the Board in a given year. Table 2 sets out some aggregate data by calendar year.

TABLE 2:

Number of Claims and Costs Awarded by Calendar Year

\begin{tabular}{|c|c|c|}
\hline Year & Number of Claims & Costs Awarded \\
\hline $\mathbf{2 0 0 4}$ & 22 & $\$ 457,262.99$ \\
\hline $\mathbf{2 0 0 5}$ & 29 & $\$ 1,150,675.45$ \\
\hline $\mathbf{2 0 0 6}$ & 17 & $\$ 177,580.92$ \\
\hline $\mathbf{2 0 0 7}$ & 34 & $\$ 689,119.89$ \\
\hline $\mathbf{2 0 0 8}$ & 34 & $\$ 468,973.55$ \\
\hline $\mathbf{2 0 0 9}$ & 40 & $\$ 1,012,342.74$ \\
\hline $\mathbf{2 0 1 0}$ & 23 & $\$ 590,481.44$ \\
\hline $\mathbf{2 0 1 1}$ & 35 & $\$ 1,051,924.31$ \\
\hline $\mathbf{2 0 1 2}$ & 22 & $\$ 361,731.62$ \\
\hline $\mathbf{2 0 1 3}$ & 6 & $\$ 158,775.77$ \\
\hline $\mathbf{2 0 1 4}$ & 57 & $\$ 1,343,840.03$ \\
\hline
\end{tabular}

The coalition of landowner intervener category received the largest aggregate amount of costs granted by the Board during the time period covered in this study, receiving almost double the amount of the next highest category of individual landowner. Figure 2 illustrates the total amounts awarded by category of intervener and the percentage of the total costs awarded by the Board.

One reason why the coalition of landowner intervener category has received the largest amount of costs awards (representing 46 percent of all awards) may simply be due to the Board policy of encouraging such coalitions in project hearings. ${ }^{71}$ First Nations have a much smaller number of claims (53) than landowners (223 of individual and coalitions combined), but have a relatively large average award amount $(\$ 28,896.43)$. This is likely due to the fact that First Nations intervene in large oil sands projects with typically more complex issues which result in larger costs claims for expert fees. In contrast, public interest groups who also tend to intervene in larger projects have a much lower average award amount $(\$ 15,720.22)$. There are relatively few entries for public interest groups because of the need to demonstrate an affected interest in land for costs eligibility under section 28 of the Energy Resources

71 The extent to which a participant is economical in its submissions or consolidates its concerns with other participants who share common concerns has always been a prescribed factor for the Board to consider in exercising its costs discretion, as Part III illustrates. 
Conservation Act prior to 2013. Likewise, there are only a few entries for a statutory body because of Board policy not to grant costs in favour of publicly funded entities. ${ }^{72}$

\section{Figure 2:}

\section{Total Cost Awards}

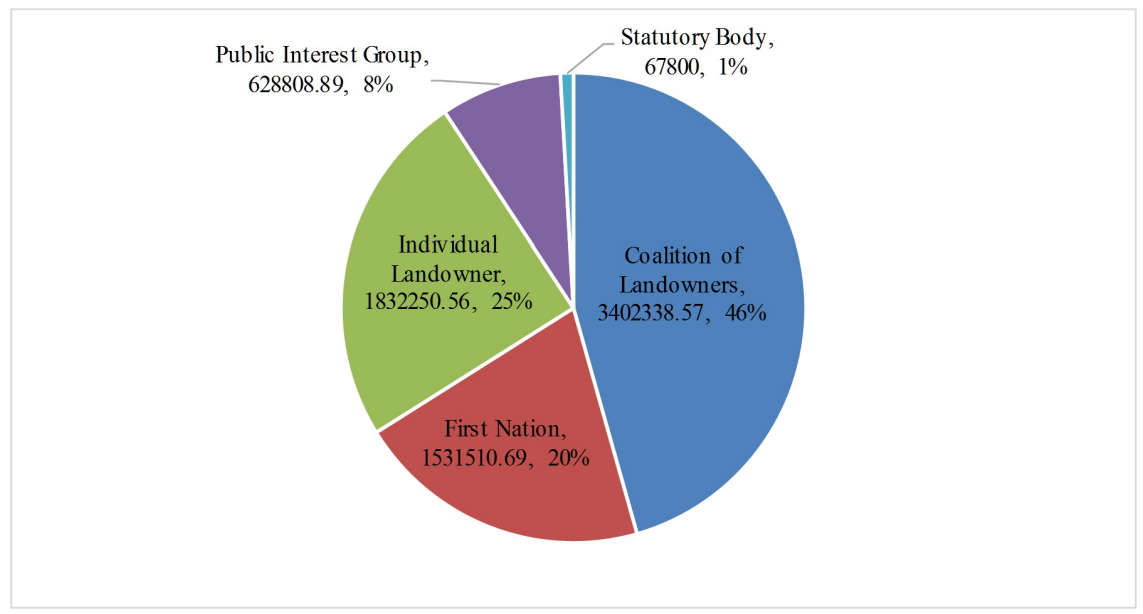

Table 3 sets out the number of claims and average amounts for each category of intervener.

TABLE 3:

Number of Claims and Average Costs Award Per Category

\begin{tabular}{|l|c|c|c|}
\hline Intervener & $\begin{array}{c}\text { Number of } \\
\text { Claims }\end{array}$ & Mean Costs Award & $\begin{array}{c}\text { Mean Percentage of } \\
\text { Costs Claim }\end{array}$ \\
\hline Coalition of Landowners & 111 & $\$ 30,651.70$ & 0.7344 \\
\hline First Nation & 53 & $\$ 28,896.43$ & 0.5985 \\
\hline Individual Landowner & 112 & $\$ 16,359.38$ & 0.7129 \\
\hline Public Interest Group & 40 & $\$ 15,720.22$ & 0.6538 \\
\hline Statutory Body & 3 & $\$ 22,600$ & 0.4717 \\
\hline
\end{tabular}

It is revealing to examine the overall distribution of costs amounts across the expert categories. The data shows that lawyers claimed and received the majority of awards during time period covered in this study. The total amount of costs claimed by interveners on behalf of their experts was $\$ 10,620,906.81$, and lawyers' fees account for 56 percent of this total amount claimed. The total amount of costs awarded by the Board was $\$ 7,462,708.71$, and lawyers' fees account for an even higher percentage of this amount at 65 percent of total costs awarded. Figure 3 illustrates the distribution of total costs claimed and awarded across the six categories of expert in the study, and the horizontal axis lists the categories in ascending order of total costs awarded by the Board. 
Figure 3:

COSTS BY TYPE OF EXPERT

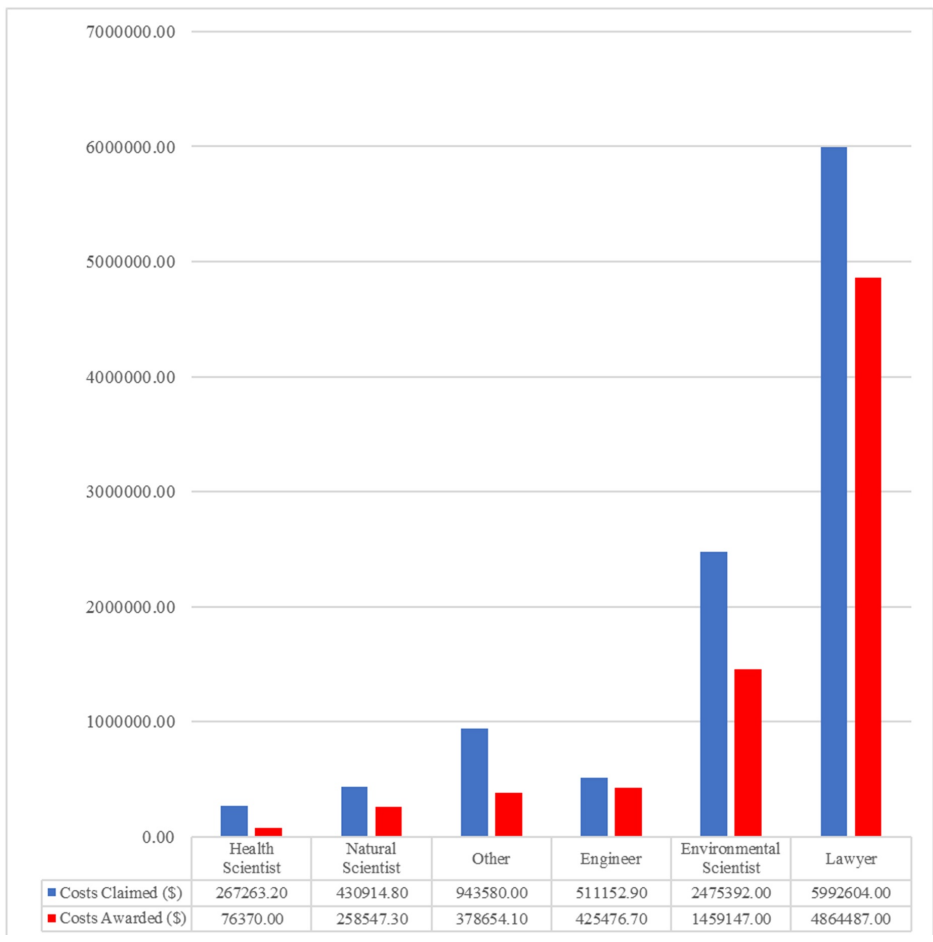

Figure 3 illustrates the significant extent to which legal fees have consumed the majority of costs awards granted by the Board during the period of this study relative to the other five categories of expert. Environmental scientists are a distant second on this list, though this placement must also be considered in light of the fact that the number of claims made on behalf of environmental scientists also make up 28 percent of the total number of claims in the study ( 89 out of 319 - see Figure 1). In other words, the relatively high number of claims influences the total costs values for environmental scientists. Figure 4 compares the mean and median percentage of costs awarded across the category of experts, and shows that the environmental scientist category drops to the middle of the group when total number of claims is taken into account. 
Figure 4:

Percentage of Costs Awarded

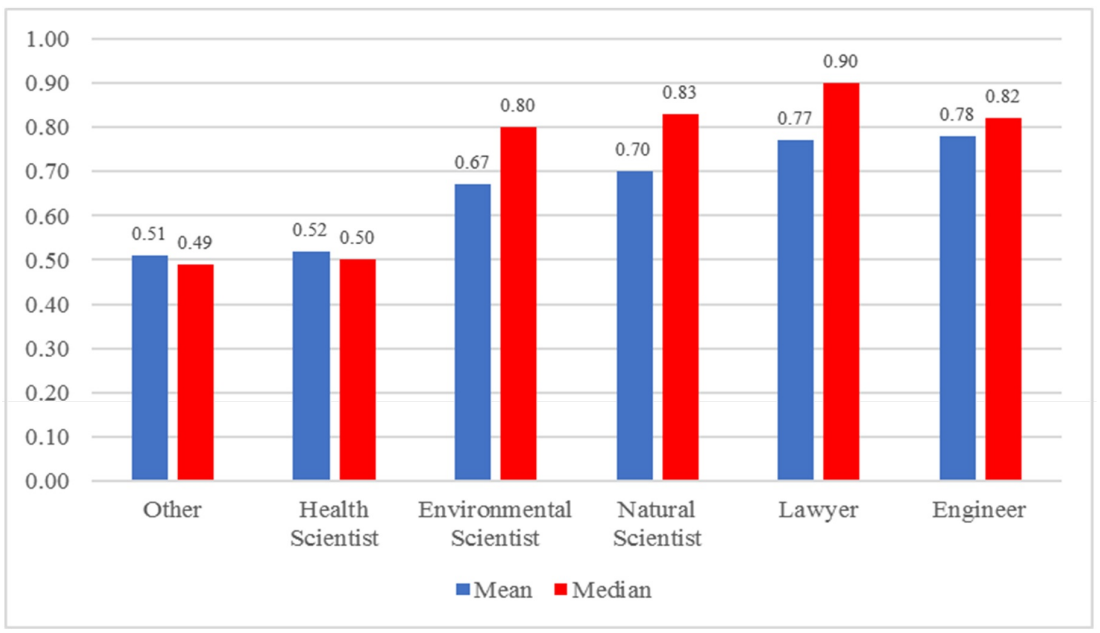

The bar chart in Figure 4 shows that the average percentage of costs awarded for two categories of expert - other and health scientists - are substantially below the overall mean value of 69 percent, and two categories - lawyer and engineer - are substantially above the mean value. The median (midpoint) value in four of the categories is substantially higher than the mean value. As noted earlier, this is due to the number of full cost award entries in those categories which pulls the median upwards. In the lawyer category, for instance, the median percentage of costs awarded is 90 percent which tells us that the majority of claims by an intervener to cover legal fees resulted in a Board costs award covering at least 90 percent of their claimed costs. As noted below, the Board awarded full costs to lawyers in 53 out of 127 claims during the time period covered in this study. We explore the data as it pertains to individual categories of expert in more detail below.

\section{LAWYERS}

Table 4 sets out calculations to assess the aggregate range of costs claimed by interveners to cover legal fees incurred by them to participate in a project hearing before the Board and amount of costs awarded by the Board for these legal fees.

\section{TABLE 4:}

Costs Claimed and Awarded to Cover Legal Fees

\begin{tabular}{|l|c|c|}
\hline & Costs Claimed & Costs Awarded \\
\hline Total & $\$ 5,992,604$ & $\$ 4,864,487$ \\
\hline Minimum & $\$ 609$ & $\$ 0$ \\
\hline Maximum & $\$ 345,898$ & $\$ 225,754.75$ \\
\hline First Quartile & $\$ 10,330.50$ & $\$ 5,251$ \\
\hline Third Quartile & $\$ 60,734.50$ & $\$ 52,253.50$ \\
\hline Mean & $\$ 47,185.85$ & $\$ 38,303.04$ \\
\hline Median & $\$ 28,350$ & $\$ 21,816$ \\
\hline
\end{tabular}


We have already observed in the aggregate data set out in Figure 1 that costs claims on behalf of lawyers make up the largest quantity of claims (127) across all experts, representing 40 percent of the total number of claims made by interveners. We have also seen in Figure 3 that the total amount awarded by the Board to cover lawyers' fees was $\$ 4,864,487$, representing 65 percent of all costs amounts awarded during the time period covered by this study. In aggregate, lawyers received approximately $\$ 3.5$ million more in Board costs awards than any other category of expert. Accordingly, it is also not surprising to observe the average amount awarded to lawyers is significantly higher than the overall value across experts. The median value of costs awarded to lawyers is $\$ 21,816$, which is more than double the overall median costs awarded for all experts $(\$ 10,563$ - see Table 1$)$. On average lawyers also asked for more costs than any other category of expert, with a median costs claim value of $\$ 28,350$. The mean value of percentage of costs awarded is 77 percent (see Figure 4) which tells us that on average the Board awarded 77 percent of a cost claim submitted by an intervener to cover their lawyer fees during the time period covered in this study.

Also noteworthy is the quartile values for percentage of costs awarded to lawyers. The first quartile is 60 percent and the third quartile is 100 percent, which tells us that threequarters of all costs awards made by the Board to cover legal fees represent at least 60 percent of the claimed amount and more than one-quarter of lawyer claims were awarded in full. In fact, the Board awarded full costs to lawyers in 53 out of the 127 total cost claims made by interveners to cover legal fees and in only 2 instances did the Board reject the costs claim in its entirety. In the remaining 72 instances where the Board awarded partial costs to cover legal fees, the most common reason given by the Board for the reduction of costs claimed (64 out of 72 entries) was because the lawyer either spent too much time on their participation or claimed preparation time in advance of the Board formally setting the hearing. The mean value of percentage of costs awarded in these cases is 62 percent, which is a 15 point drop from the overall mean value of percentage of costs awarded (77 percent - see Figure 4) to cover legal fees. In only 8 instances did the Board employ more critical reasoning that the lawyer failed to provide a meaningful contribution to a hearing, and even in those cases the mean percentage of costs awarded is still 66 percent. Similarly, where an energy company argued for no costs payable to an intervener's lawyer (10 out of 127 claims) the mean percentage of costs awarded is still 73 percent or, in other words, the Board still awarded on average 73 percent of the claimed amount.

\section{ENGINEERS}

Table 5 sets out calculations to assess the aggregate range of costs claimed by interveners to cover professional fees paid to engineers and the amount of costs awarded by the Board for such fees. 
TABLE 5:

Costs Claimed and Awarded to Cover Professional Fees Paid to Engineers

\begin{tabular}{|l|c|c|}
\hline & Costs Claimed & Costs Awarded \\
\hline Total & $\$ 511,152.87$ & $\$ 425,476.74$ \\
\hline Minimum & $\$ 1,038.75$ & $\$ 0$ \\
\hline Maximum & $\$ 59,670$ & $\$ 55,620$ \\
\hline First Quartile & $\$ 9,193.63$ & $\$ 6,762$ \\
\hline Third Quartile & $\$ 27,366.72$ & $\$ 25,377.41$ \\
\hline Mean & $\$ 23,234.22$ & $\$ 19,339.85$ \\
\hline Median & $\$ 18,753.75$ & $\$ 15,536.25$ \\
\hline
\end{tabular}

The mean and median costs values for engineers are lower than that observed for lawyers, but still higher than the overall values for experts. The total costs claimed and awarded is, of course, much lower for engineers as compared to some other categories, such as lawyers, because of the fact that engineers represent only 7 percent of the total number of claims (22 claims - see Figure 1). Similar to lawyers however, the mean value of percentage of costs awarded is 78 percent (see Figure 4) which represents the highest percentage of all the expert categories. Likewise, the first quartile of percentage of costs awarded for engineers is 70 percent and the third quartile is 100 percent, which tells us that three-quarter of all cost awards made by the Board to cover engineering fees represent at least 70 percent of the claimed amount and more than one-quarter of engineer claims are awarded in full. In fact, the Board awarded full costs in eight out of the 22 cost claims made by interveners on behalf of an engineer and the Board awarded no costs in only 1 instance (correlating with the energy company's position of no costs in that case).

In the 14 cases where the Board granted partial or no costs to an engineer, the most common reason for the reduction was that the engineer failed to provide a meaningful contribution to a hearing, yet the Board still awarded 68 percent of the claim on average in these cases. Interestingly in the 19 cases where the energy company argued for a reduction in the costs claim of an engineer, the mean percentage awarded by the Board to engineers is 82 percent. In other words, arguments by the energy company for a reduction in an engineer's cost claim resulted in the Board still awarding, on average, 82 percent of the claimed amount. Finally, we note that the energy company argued for no costs payable to an engineer in 3 out of the 22 total claims made by an intervener to cover engineering fees.

\section{ENVIRONMENTAL SCIENTISTS}

Table 6 sets out calculations to assess the aggregate range of costs claimed by interveners to cover professional fees paid to environmental scientists and the amount of costs awarded by the Board for such fees. Experts in this category include ecologists or consultants in matters such as air quality, dispersion modelling, water quality, light pollution, noise measurement, and risk planning or emergency response systems. 
TABLE 6:

Costs Claimed and Awarded to Cover Professional Fees

Paid to Environmental Scientists

\begin{tabular}{|l|c|c|}
\hline & Costs Claimed & Costs Awarded \\
\hline Total & $\$ 2,475,392$ & $\$ 1,459,174$ \\
\hline Minimum & $\$ 525$ & $\$ 0$ \\
\hline Maximum & $\$ 209,010$ & $\$ 146,053$ \\
\hline First Quartile & $\$ 3,812.50$ & $\$ 1,854.50$ \\
\hline Third Quartile & $\$ 35,514.40$ & $\$ 22,680$ \\
\hline Mean & $\$ 27,813.40$ & $\$ 16,395.20$ \\
\hline Median & $\$ 15,795$ & $\$ 9,540$ \\
\hline
\end{tabular}

Environmental scientists represent the second largest total of costs claims (89 entries) made by interveners during the time period covered in this study. As such, the total amount of costs claimed and awarded by the Board is relatively high for environmental scientists. However, the mean and median costs values are in the mid-range relative to all categories and, in particular, the median value of costs awarded by the Board $(\$ 9,540)$ is very close to the overall median value for all experts $(\$ 10,563$ - see Table 1$)$. The large difference between the mean and median values for costs awards tells us there are some high outlier awards skewing the median value upwards, and this is further demonstrated by the third quartile value which tells us three-quarters of all costs awards made by the Board to cover fees of environmental scientists is equal to or lower than $\$ 22,680$. In fact, there are only two costs awards that exceed $\$ 100,000$ to an environmental scientist and interestingly both awards were granted for the same well licence or pipeline project hearing in 2005.

The mean value of percentage of costs awarded to cover the fees of an environmental scientist is 67 percent (see Figure 4). In other words, on average the Board's costs award represents 67 percent of the claim made by an intervener to cover the fees of their environmental science expert. The first quartile value is 41 percent and the third quartile value is 100 percent, which tells us that three-quarters of all costs awards made by the Board to cover the fees of an environmental scientist represent at least 41 percent of the claimed amount and more than one-quarter of these claims are awarded in full. In fact, the Board awarded full costs in almost half of the 89 claims made by interveners on behalf of an environmental scientist (full costs are awarded in 41 out of 89 claims) and the Board awarded no costs in 10 instances (correlating with the energy company's position of no costs in 8 out of those 10 instances).

In the 48 cases where the Board granted partial or no costs to an environmental scientist, the most common reason for the reduction is that the environmental scientist failed to provide a meaningful contribution to the hearing. In those cases, the Board awarded on average only 38 percent of the claimed amount which is 29 points below the overall mean for environmental scientists (67 percent - see Figure 4). This difference is much larger than what was observed for engineers (a 10 point drop). In four cases, the Board felt the environmental scientist was not credible or qualified, and in these cases the Board awarded on average only 26 percent of the claimed amount and in no such case was the award more than 50 percent of the claimed amount. 
In cases where the energy company argued for no costs payable to cover the fees of an environmental scientist ( 25 out of 89 claims), the mean percentage awarded by the Board was 43 percent. In contrast, the Board awarded on average 87 percent of the claimed amount for an environmental scientist in those cases ( 19 out of 89 claims) where the energy company submitted no position on the claim. In the 44 cases where the energy company argued for reduced costs the mean percentage awarded by the Board to engineers is 72 percent, which is very close to the overall average for environmental scientists.

\section{HEALTH SCIENTISTS}

Table 7 sets out calculations to assess the aggregate range of costs claimed by interveners to cover professional fees paid to health scientists and the amount of costs awarded by the Board for such fees. Experts in this category include a physician or other health professional such as a livestock veterinarian.

TABLE 7:

Costs Claimed and Awarded to Cover

Professional fees Paid to Health Scientists

\begin{tabular}{|l|c|c|}
\hline & Costs Claimed & Costs Awarded \\
\hline Total & $\$ 267,263.20$ & $\$ 76,370$ \\
\hline Minimum & $\$ 1,100$ & $\$ 0$ \\
\hline Maximum & $\$ 81,600.75$ & $\$ 24,937.50$ \\
\hline First Quartile & $\$ 4,066.60$ & $\$ 1,000$ \\
\hline Third Quartile & $\$ 24,937.50$ & $\$ 6,075$ \\
\hline Mean & $\$ 20,558.71$ & $\$ 5874.62$ \\
\hline Median & $\$ 11,500$ & $\$ 5,000$ \\
\hline
\end{tabular}

Health scientists represent the smallest number of costs claims (13 entries) made by interveners during the time period covered by this study, and accordingly have the lowest total costs awarded $(\$ 76,370)$. Health scientists also have relatively low distribution calculations. We note, for example, that the maximum award granted by the Board to cover the fees of a health scientist $(\$ 24,937.50)$ is only slightly higher than the median costs award to cover legal fees $(\$ 21,816$ - see Table 4$)$. The median costs award value to cover the fees of a health scientist is only $\$ 5,000$. The third quartile value tells us that three-quarters of all awards made by the Board to cover health scientist fees were equal to or less than $\$ 6,075$, and only two of the 13 costs claims resulted in a costs award to a health scientist greater than $\$ 10,000$. The mean value of percentage of costs awarded to cover the fees of a health scientist is 52 percent. In other words, on average the Board awarded 52 percent of the claim made by an intervener to cover the fees of their health science expert. The Board awarded full costs in three of the 13 claims, and the Board awarded no costs in three of the 13 claims (correlating with the energy company's position of no costs in each of these three instances).

In the 10 cases where the Board granted partial or no costs to a health scientist, the most common reason for the reduction was that the health scientist gave incomplete or unsatisfactory evidence. The number of entries is small, though we do observe that the two costs decisions where the Board felt the health scientist was non-credible or unqualified were also the two largest claims made by an intervener on behalf of a health scientist in this study 
$(\$ 81,600.75$ and $\$ 64,327.50)$ and the Board rejected the costs claim in its entirety on both occasions. We also note with interest that the energy company argued for no costs in eight of the 13 costs claims made by interveners to cover professional fees incurred to retain a health scientist.

\section{NATURAL SCIENTISTS}

Table 8 sets out calculations to assess the aggregate range of costs claimed by interveners to cover professional fees paid to natural scientists and the amount of costs awarded by the Board for such fees. Experts in this category include scientists who specialize in the so-called hard sciences like chemistry, physics, biology, or geology.

TABLE 8:

Costs Claimed and Awarded to Cover

Professional Fees Paid to Natural Scientists

\begin{tabular}{|l|c|c|}
\hline & Costs Claimed & Costs Awarded \\
\hline Total & $\$ 430,914.80$ & $\$ 258,547.30$ \\
\hline Minimum & $\$ 2,450$ & $\$ 0$ \\
\hline Maximum & $\$ 1,772.50$ & $\$ 43,612.80$ \\
\hline First Quartile & $\$ 7,730$ & $\$ 4,152.50$ \\
\hline Third Quartile & $\$ 21,837.50$ & $\$ 18,484.50$ \\
\hline Mean & $\$ 19,587.04$ & $\$ 11,752.15$ \\
\hline Median & $\$ 11,012.50$ & $\$ 6,966.25$ \\
\hline
\end{tabular}

The fees of a natural scientist represent 22 costs claims made by interveners in this study (see Figure 1). The median costs award is $\$ 6,966.25$, and like some other categories of expert, the large difference between mean and median values suggests there are some high outlier awards granted by the Board to cover the fees of a natural scientist. The two outlier awards are $\$ 41,880$ and $\$ 43,612.80$. The third quartile value for costs awarded tells us that three-quarters of all cost awards made to intervenors to cover the professional fees of a natural scientist were equal to or less than $\$ 18,484.50$. The mean value of percentage of costs awarded to a natural scientist is 70 percent (see Figure 4) which sits at about the overall average for all expert categories. While the average amounts and total costs awarded to cover the fees of a natural scientist seem relatively low, it is also apparent that costs claims made by an intervener on behalf of a natural scientist are also somewhat lower on average. The median claimed amount for a natural scientist is $\$ 11,012.50$, which is similar to that observed for a health scientist $(\$ 11,500$ - see Table 7) but far less than the median cost amount claimed by an intervener for the fees of environmental scientists $(\$ 15,795$ - see Table 6), engineers $(\$ 18,753.75$ - see Table 5), and lawyers $(\$ 28,350$ - see Table 4$)$. The first quartile of percentage of costs awarded for natural scientists is 0.50 and the third quartile is 1.0 , which tells us that three-quarter of all awards made by the Board to cover natural scientist fees represent at least 50 percent of the claimed amount and more than one-quarter of natural scientist claims are awarded in full. In fact, the Board awarded full costs in 11 out of the 22 cost claims made by interveners on behalf of a natural scientist and the Board awarded no costs in only two instances (correlating with the energy company's position of no costs in both of those cases). Interestingly, one of the cases where the Board granted no 
costs is also the case with the highest claimed amount $(\$ 81,772.50)$ made by an intervenor to cover the fees of a natural scientist.

In the 11 cases where the Board granted partial or no costs to a natural scientist, the most common reason for the reduction was that the scientist failed to provide a meaningful contribution to the hearing. In those cases, the mean percentage of costs awarded is 38 percent, which is 32 points below the overall mean for natural scientists ( 70 percent - see Figure 4). This large drop is similar to that observed for environmental scientists (29 percentage points). In cases where the energy company argued for no costs (10 out of 22 claims) the mean percentage awarded by the Board to cover the fees of a natural scientist is 46 percent. In other words, arguments by the energy company for no costs to a natural scientist results in the Board awarding, on average, 46 percent of a claimed amount which is significantly lower than the overall average for natural scientists (70 percent).

\section{OTHER}

The final category of expert in this study is "other." This category was used to capture any type of expert not covered by the above-named categories. Examples of where the "other" category is used include a person with expertise in land valuation, a historian, a consultant on indigenous matters, and non-lawyers who represent interveners before the Board. Effort was made to use this category sparingly, but it still represents 46 entries, which represents 14 percent of all claims in this study (see Figure 1). Table 9 sets out calculations to assess the aggregate range of costs claimed by interveners to cover professional fees paid to experts in the "other" category and the amount of costs awarded by the Board for such fees.

TABLE 9:

Costs Claimed and Awarded to Cover

Professional fees Paid to Other Experts

\begin{tabular}{|l|c|c|}
\hline & Costs Claimed & Costs Awarded \\
\hline Total & $\$ 943,580$ & $\$ 378,654.10$ \\
\hline Minimum & $\$ 960$ & $\$ 0$ \\
\hline Maximum & $\$ 131,125$ & $\$ 40,386$ \\
\hline First Quartile & $\$ 4,883.75$ & $\$ 1,958.18$ \\
\hline Third Quartile & $\$ 24,984.71$ & $\$ 11,406.25$ \\
\hline Mean & $\$ 20,512.61$ & $\$ 8,231.61$ \\
\hline Median & $\$ 12,250$ & $\$ 5,060$ \\
\hline
\end{tabular}

The median value of costs awarded by the Board to cover the fees of experts in the "other" category $(\$ 5,060)$ is lower than all other categories except health scientists $(\$ 5,000-$ see Table 7). Similarly, the third quartile value for costs awarded tells us that three-quarters of all awards made to intervenors to cover the professional fees of an expert captured in the "other" category was equal to or less than $\$ 11,406.25$. The mean value of percentage of costs awarded to persons in this category is 51 percent, which tells us on average the Board awarded 51 percent of the amount claimed by an intervener on behalf of these experts. This is the lowest percentage of all the expert categories (see Figure 4). 
In the 35 cases where the Board granted partial or no costs to an expert in this category, the most common reason for the reduction was that the person failed to provide a meaningful contribution to the hearing. In these cases, the mean percentage of costs awarded is 27 percent, which is 24 percentage points below the overall mean for this category (51 percent - see Figure 4). In cases where the energy company argued for no costs (20 out of 46 claims) the mean percentage awarded by the Board to experts in the "other" category is also 27 percent. In other words, arguments by the energy company for no costs payable to these experts resulted in the Board awarding, on average, 27 percent of the claimed amount.

\section{Conclusions}

The overall objective of this study was to assess the Board's costs regime since its inception in 1978 and provide analysis on how the Board has exercised its discretion over costs in more recent times. We observed that the Board's governing legislation provides it with express authority to grant costs awards to hearing participants, and that the Board assigns liability for costs to the energy company whose project is the subject of the hearing. We also made specific mention of the Alberta Court of Appeal's 2012 Kelly decision, wherein the Court not only suggests it is appropriate for energy companies to be liable for hearing costs, but that it might be a necessary component of Board hearings if the AER is to fulfil its mandate to the public.

Over the years the AER has gained significant discretion to administer its power to make costs awards. In the early days, the Board was authorized to grant costs in favour of landowners affected by an energy project and the prescribed list of considerations essentially amounted to whether the landowner's contribution to the hearing was relevant. At times, the Board struggled with eligibility questions as hearing participants in energy project applications began to include not only landowners but also municipalities and public interest groups. In 2013, the Responsible Energy Development Act empowered the AER with almost complete discretion over how it administers costs and removed the restriction on eligibility to landowners. The Board responded with new rules and policy to guide how it would exercise that discretion.

Given the very discretionary nature of the current AER costs regime and the significance of costs awards in providing interveners with an opportunity to exercise hearing entitlements, we thought it would be insightful to examine how the Board has exercised its discretion in making costs awards to eligible participants. We analyzed all energy project costs decisions issued by the Board from 2004 to 2014. At the time of our analysis, these were all the energy project costs decisions published on the AER website. Since December 2014, the AER has published five additional costs decisions and, while these more recent decisions are not included in our statistical analysis, we have made some observations about these decisions in Part III above, and give some brief commentary below.

The two primary observations are as follows: (1) costs awards made by the Board have overwhelmingly been applied to cover the legal fees incurred by interveners to participate before the Board in project hearings; and (2) in exercising its discretion the Board seems to have distinguished its evaluation of certain types of expert — in particular, the Board seems less sensitive to the quality or relevance of the contribution made by a lawyer or engineer versus that of an environmental scientist or health scientist. We conclude this article by 
further elaborating on these two observations, and suggesting how the data provided by this study on individual claims may have some utility in providing prospective hearing participants with a better sense of what to expect in claims submitted under the AER Rules.

Legal fees dominated the costs award process administered by the Board from 2004 to 2014. This fact is borne out by a number of observations set out in Part IV, including:

- the number of claims made by hearing participants to cover legal fees incurred to participate in a project hearing represent 40 percent of the total number of claims considered by the Board;

- the total amount of costs awarded by the Board to cover legal fees represents 65 percent of all costs awarded by the Board and in actual dollars exceeds the next highest category of expert fees by approximately $\$ 3.5$ million;

- legal fees are the basis for both the highest claimed amount by a hearing participant for one expert and the highest cost award made by the Board to cover the fees of an expert;

- legal fees are the basis for 12 of the 14 costs awards over $\$ 100,000$ made by the Board to cover the fees of an expert;

- the average value of a costs award made by the Board to cover legal fees is the highest of all types of experts, and is almost double the overall average;

- on average the Board awarded 77 percent of legal fees claimed by a hearing participant, and three-quarters of all awards to cover legal fees represent at least 60 percent of the claimed amount;

- the Board awarded full costs to lawyers in 53 out of the 127 total cost claims made by participants to cover legal fees and in only two instances did the Board reject the claim for legal fees in its entirety.

The five costs decisions issued by the AER since December 2014 and up to the time of writing illustrate that legal fees continue to dominate cost awards made by the Board under the AER Rules. ${ }^{73}$

The average percentage of costs awarded is significantly higher for costs claims made on behalf of an engineer ( 78 percent of the claim) or a lawyer ( 77 percent of the claim), in comparison to claims made on behalf of other types of experts who have appeared before the Board. Perhaps even more noteworthy however, the data suggests the Board was less 
sensitive towards the quality of a contribution made by an engineer or lawyer even in cases where the Board is critical of the participation of these experts.

The most common reason given by the Board for reducing a claim for a lawyer is that the claim is for too much time in preparation for a hearing, but the Board still awarded 62 percent of the claim for legal fees on average in those instances. In the few cases where the Board felt a lawyer did not make a meaningful contribution to a hearing, the Board still awarded 66 percent of the claim on average. Likewise for engineers, the most common reason given by the Board for reducing a claim for an engineer was because the Board did not feel the engineer made a meaningful contribution, though the Board still awarded on average 68 percent of the claim in these cases.

Consider now these numbers for lawyers and engineers with the costs claims submitted on behalf of an environmental scientist, the second largest number of claims behind lawyers in this study. In cases where the Board felt an environmental scientist did not make a meaningful contribution to a hearing, the Board awarded only 38 percent of the claim on average. The Board granted full costs to an environmental scientist in 41 out of 89 claims, which is a slightly larger fraction of claims than that observed for lawyers (53 out of 127 claims) or engineers ( 8 out of 127 claims). However, the Board also rejected a cost claim in its entirety more often for environmental scientists (10 out of 89 claims) than for lawyers (two out of 89 claims) or engineers (one out of 22 claims).

The energy company argued that the Board should reject the costs claim in its entirety in 76 of the 319 cost claims included in this study. These instances would seemingly represent cases where the energy company is most adversarial towards the participation of an expert in terms of either or both of the expert's monetary claim or contribution to the hearing before the Board. Of these 76 claims, 25 of them relate to a claim submitted by a participant on behalf of an environmental scientist. In these cases, the Board awarded on average 43 percent of the claimed amount. To illustrate the impact of an adversarial position from the energy company against an environmental scientist, consider that the Board awarded on average 87 percent of the cost claim for an environmental scientist in cases where the energy company submitted no position on their claim. Another 20 of the 76 claims where the energy company argued for no costs payable relate to a claim submitted by a participant on behalf an expert coded as "other" in this study. In these instances, the Board awarded only 27 percent of the claim on average. In comparison, there are 10 instances where an energy company asked the Board to reject a lawyer's claim completely, and the Board still awarded on average 73 percent of the claim in these instances.

It is unlikely a hearing participant will receive the full amount claimed for their costs to retain experts at an AER hearing. Between 2004 and 2014, half of all costs awards made by the Board for an expert were between the amounts of $\$ 3,167.50$ and $\$ 26,631.65$. The third quartile value tells us that three-quarters of all costs awards were equal to or less than $\$ 26,631.65$ for an expert. So obtaining an award higher than $\$ 25,000$ to cover the fees incurred to retain an expert is more the exception than the norm. Indeed, the median value in this study of costs awarded to cover the fees of an expert is only $\$ 10,563$. In the decisions studied here the Board awarded on average 69 percent of the claimed amount. 
The changes to the costs process implemented with the enactment of the Responsible Energy Development Act in 2013 and the subsequent policy change by the AER to conduct a more limited review of costs claims going forward have altered the costs award process for energy project hearings since 2014. Eligibility for costs no longer seems to be a contested matter for persons who have otherwise been granted standing to participate in an AER hearing. However, the process by which cost claims are administered and decided upon is less transparent than it was previously.

The list of considerations now set out in the AER Rules codifies much of what we have observed in our examination of AER costs decisions issued since 2004. The Board scrutinizes a costs claim to assess whether the expert(s) are suitably qualified to address matters relevant to the hearing, are efficient and responsible in their preparation for and participation in the hearing, and will generally make a meaningful contribution towards a resolution of the issues in question. We hope the analysis and data provided herein sheds additional light into these considerations, and provides a prospective AER hearing participant with an even better sense of what to expect in claims submitted under the AER Rules or in negotiations with energy companies in an attempt to recover costs incurred to participate in an AER energy project hearing. 